\title{
Przedsięwzięcia prośrodowiskowe finansowane ze środków funduszy unijnych
}

\section{Wstęp}

W latach 2014-2020 Unia Europejska przeznaczyła dla Polski 82,5 mld euro na realizację polityki spójności. Podstawowym założeniem polityki spójności jest pomoc w wyrównaniu warunków ekonomicznych i społecznych regionów Unii w celu wzmocnienia spójności gospodarczej, społecznej i terytorialnej. Środki otrzymane w ramach wsparcia unijnego zainwestowane zostały $\mathrm{w}$ infrastrukturę transportową ${ }^{1}$, ochronę środowiska i energetykę ${ }^{2}$ oraz projekty

${ }^{1}$ Budowa trasy północno-zachodniej miasta Płocka. Projekt realizowany z Regionalnego Programu Operacyjnego Województwa Mazowieckiego na lata 2014-2020, Działanie 7.1 Infrastruktura drogowa. Wartość projektu: 97169461,19 zł, dofinansowanie z UE: $76287933,17 \mathrm{zl}$.

${ }^{2}$ Przebudowa Gminnego Ośrodka Kultury w Malczycach wraz z zastosowaniem rozwiązań energooszczędnych. Projekt realizowany z Regionalnego Programu Operacyjnego Województwa Dolnośląskiego 2014-2020, Działanie 4.3 Dziedzictwo kulturowe. Wartość projektu: 2211 816,32 zł, dofinansowanie z UE: 1690 812,45 zł; Modernizacja elewacji budynku Uniwersytetu Łódzkiego oraz budynku biblioteki — jednej z pierwszych powojennych bibliotek naukowych w kraju, która gromadzi bezcenne piętnastowieczne inkunabuły, starodruki i księgi rękopiśmienne. Dotacja z Programu Operacyjnego Infrastruktura i Środowisko 2014-2020, Działanie 1.3 Wspieranie efektywności energetycznej w budynkach poddziałanie 1.3.1 Wspieranie efektywności energetycznej w budynkach użyteczności publicznej. Wartość projektu: 6036 231,09 zł, dofinansowanie z UE: 3611 229,01 zł. 
m.in. z dziedziny kultury ${ }^{3}$, zatrudnienia, edukacji ${ }^{4}$ czy przeciwdziałania wykluczeniu społecznemus

Jednym z celów polityki Unii Europejskiej (UE) w państwach członkowskich jest ochrona środowiska przyrodniczego, dlatego coraz większa liczba inwestorów korzysta ze środków przeznaczonych na ochronę środowiska przyrodniczego ${ }^{6}$. UE propaguje wdrażanie proekologicznych inicjatyw służących polepszeniu warunków życia obywateli państw członkowskich poprzez poprawę kondycji środowiska naturalnego. W ciągu ostatnich lat polityka proekologiczna stała się bardzo powszechna zarówno w Polsce, jak i w innych państwach członkowskich.

Dofinansowania na realizację projektów wspierających ochronę klimatu realizowane są przede wszystkim w ramach Programu Operacyjnego Infrastruktura i Środowisko (POIiŚ), a także Regionalnych Programów Operacyjnych oraz Funduszu Spójności. Warto również wspomnieć o Programie LIFE, który jest jedynym instrumentem finansowym Unii Europejskiej poświęconym wyłącznie współfinansowaniu projektów z dziedziny ochrony środowiska i klimatu. Wsparcie finansowe na działania prośrodowiskowe można również uzyskać dzięki tzw. funduszom norweskim, tj. Norweskiemu Mechanizmowi Finansowemu (NMF) i Mechanizmowi Finansowemu Europejskiego Obszaru Gospodarczego (MF EOG) $)^{7}$

${ }^{3}$ Budowa organów koncertowych oraz zakup instrumentów i niezbędnego wyposażenia dla NOSPR w Katowicach. Projekt sfinansowany z Programu Operacyjnego Infrastruktura i Środowisko 2014-2020. Działanie 8.1 Ochrona dziedzictwa kulturowego i rozwój zasobów kultury. Wartość projektu: 20594 633,15 zł, dofinansowanie z UE: 14286353,75 zł.

${ }^{4}$ „Zintegrowany Program Rozwoju Uniwersytetu Śląskiego w Katowicach” realizowany w ramach Programu Operacyjnego Wiedza Edukacja Rozwój, współfinansowanego ze środków Unii Europejskiej w ramach Europejskiego Funduszu Społecznego. Celem projektu jest podniesienie kompetencji zawodowych, informatycznych, językowych, analitycznych, odpowiadających potrzebom gospodarki, rynku pracy i społeczeństwa poprzez realizację programu rozwoju kompetencji w tym: certyfikowanych szkoleń i warsztatów, wizyt studyjnych, dodatkowych zadań praktycznych. Okres trwania projektu: 1.10.2018 -30.09.2022. Wartość projektu: 13029 558,52 zł, dofinansowanie z UE: 12638671,74 zł.

${ }^{5}$ Projekt — stop wykluczeniu. Projekt realizowany w ramach Działania 9.1 Aktywizacja społeczno-zawodowa osób wykluczonych i przeciwdziałanie wykluczeniu społecznemu z Regionalnego Programu Operacyjnego Województwa Mazowieckiego na lata 2014-2020. Wartość projektu: 839 065,50 zł, dofinansowanie z UE: 797 112,22 zł.

${ }^{6}$ L. Bylicki, Ochrona środowiska w Unii Europejskiej, „Zeszyty Naukowe PWSZ w Płocku Nauki Ekonomiczne" 2014, T. 20, s. 185-199.

${ }^{7}$ To dwa instrumenty finansowe ustanowione przez państwa darczyńców (Norwegię, Islandię i Liechtenstein) w zamian za dostęp do wspólnego rynku UE. 


\section{Źródła finansowania polityki spójności}

Zdaniem J. McCormick polityka spójności podzielona jest na dwie części: regionalną i socjalną̧. Polityka spójności bywa też utożsamiana z pojęciami polityki strukturalnej i regionalnej’. Posługiwanie się tymi pojęciami zamiennie wynika również z faktu, że podstawowym instrumentem finansowym polityki regionalnej są fundusze strukturalne. Na europejskie fundusze strukturalne i inwestycyjne składa się pięć głównych funduszy wspierających rozwój gospodarczy we wszystkich państwach $\mathrm{UE}^{10}$.

Celem europejskiej polityki spójności w latach 2014-2020 jest skuteczne wdrożenie Strategii Europa 202011, która zakłada zrównoważony rozwój oraz długotrwały wzrost gospodarczy poprzez budowanie gospodarki opartej na wiedzy, gospodarowaniu zasobami oraz promowaniu technologii przyjaznych dla środowiska ${ }^{12}$. W Polsce fundusze strukturalne w perspektywie 2014-2020 wdrażane są poprzez 6 krajowych programów operacyjnych ${ }^{13}$ zarządzanych przez Ministerstwo Infrastruktury i Rozwoju oraz przez 16 programów regionalnych zarządzanych przez urzędy marszałkowskie ${ }^{14}$.

${ }^{8}$ J. McCormick, Zrozumieć Unię Europejska, Wydawnictwo Naukowe PWN, Warszawa 2010, s. 282-295.

9 A. Ryszkiewicz, Od konwergencji do spójności i efektywności, Szkoła Główna Handlowa. Oficyna Wydawnicza, Warszawa 2013, s. 59-82.

${ }^{10}$ Europejski Fundusz Rozwoju Regionalnego (EFRR); Europejski Fundusz Społeczny (EFS); Fundusz Spójności; Europejski Fundusz Rolny na rzecz Rozwoju Obszarów Wiejskich (EFRROW); Europejski Fundusz Morski i Rybacki (EFMR).

${ }^{11}$ Europa 2020 - w 2010 r. Komisja Europejska opublikowała komunikat pt. „EUROPA 2020: Strategia na rzecz inteligentnego i zrównoważonego rozwoju sprzyjającego włączeniu społecznemu". Dokument ten stanowił rozwinięcie postanowień zawartych w art. 173 Traktatu o funkcjonowaniu Unii Europejskiej (TFUE), zgodnie z którym „Unia i państwa członkowskie czuwają nad zapewnieniem warunków niezbędnych dla konkurencyjności przemysłu Unii” oraz art. 179-189 TFUE dotyczących badań i rozwoju technologicznego, Komisja Europejska, Bruksela, 3.3.2010, KOM(2010) 2020; zob. J. Szlachta, Polityka rozwojowa w kontekście polityki spójności - przypadek Polski w latach 2014-2020, „Prace i Materiały Instytutu Rozwoju Gospodarczego SGH” 2016, Vol. 98, s. 131-150.

${ }_{12}$ M. Gasz, Strategia Europa 2020 - założenia i perspektywy realizacji, „Nierówności Społeczne a Wzrost Gospodarczy” 2014, z. 38, s. 85-97. Najważniejszym dokumentem określającym strategię inwestowania w perspektywie 2014-2020 w Polsce jest Umowa Partnerstwa Programowanie perspektywy finansowej 2014-2020. Aktem prawnym, który zapewnia ramy prawne po stronie polskiej dla realizacji postanowień Umowy Partnerstwa, jest ustawa z dnia 11 lipca 2014 r. o zasadach realizacji programów w zakresie polityki spójności finansowanych w perspektywie finansowej 2014-2020 (t.j. Dz.U. 2020, poz. 818, tzw. ustawa wdrożeniowa).

${ }_{13}$ Program Operacyjny Inteligentny Rozwój; Program Operacyjny Polska Cyfrowa; Program Operacyjny Infrastruktura i Środowisko; Program Operacyjny Polska Wschodnia; Program Operacyjny Wiedza Edukacja Rozwój; Program Operacyjny Pomoc Techniczna.

${ }_{14}$ Zob. E. Michalik, Wspieranie rozwoju regionalnego w Polsce w perspektywie finansowej 2014-2020, „Studia Ekonomiczne” 2017, nr 319, s. 127-136. 
Przyszła perspektywa finansowa to jednak nie tylko polityka spójności. Pulę dostępnych dla beneficjentów różnego rodzaju środków budowały będą również polityka rolna oraz 2 nowe fundusze: Fundusz Sprawiedliwej Transformacji oraz Instrument na Rzecz Odbudowy i Zwiększania Odporności. W wielu aspektach wdrażanie funduszy w ramach polityki spójności będzie podobne jak w latach 2014-2020, ponieważ pozostaną programy zarządzane z poziomu krajowego i regionalnego.

Pandemia COVID-19 panująca w 2020 r. wywarła wpływ na toczące się negocjacje w sprawie unijnego budżetu, dlatego 27 maja 2020 r. Komisja Europejska przedstawiła plan odbudowy gospodarczej UE - Recovery Plan wraz z nowym narzędziem Next Generation EU, oraz propozycję odnowionych wieloletnich ram finansowych na lata $2021-2027^{15}$.

\section{Działania prośrodowiskowe współfinansowane ze środków unijnych}

Ochrona środowiska obejmuje szereg działań poświęconych racjonalnemu kształtowaniu środowiska i gospodarowaniu jego zasobami, a także przeciwdziałaniu powstawania zanieczyszczeń poprzez zmniejszenie emisyjności gospodarki zgodnie z zasadą zrównoważonego rozwoju. Przedsięwzięcia służące ochronie środowiska przyrodniczego mają przede wszystkim charakter inwestycyjny, ale mogą to też być działania pozainwestycyjne ${ }^{16}$.

Od wielu lat dzięki możliwości pozyskania dofinansowania ze środków unijnych realizowanych jest szereg działań w wielu obszarach, m.in. gospodarowania odpadami ${ }^{17}$, ochrony klimatu ${ }^{18}$ (np. cel redukcji emisji gazów cieplar-

${ }^{15}$ W chwili oddania artykułu do publikacji szczegółowe dane na temat budżetu w kolejnej perspektywie finansowej 2021-2027 nie są znane.

${ }^{16}$ M. Kożuch, Zmiany $w$ finansowaniu przedsięwzięć ochrony środowiska przyrodniczego w Polsce, ,Zeszyty Naukowe Uniwersytetu Ekonomicznego w Krakowie” 2018, nr 1 (973), s. $61-78$.

17 „Budowa Punktu Selektywnej Zbiórki Odpadów Komunalnych na terenie Gminy Żagań”. Oś Priorytetowa 4. Środowisko i kultura, Działania 4.2 Gospodarka odpadami, Regionalny Program Operacyjny Lubuskiego. Całkowita wartość projektu: 635 830,96 zł, dofinansowanie z UE: 343 718,72 zł. Zob. E. Bień, Management of Available EU Funds and The State of Municipal Waste Management in Poland, in: Proceedings of the 35th International Business Information Management Association Conference, Education Excellence and Innovation Management: A 2025 Vision to Sustain Economic Development during Global Challenges, ed. Khalid S. Soliman, Sewilla 2020, s. 9593-9606; A. Ulfik, Regional Use of European Funds in Municipal Waste Management in Poland, „European Journal of Service Management” 2018, Vol. 27/1, 3/2018, s. 351—356.

18 Wdrażanie nowoczesnych technik monitorowania powietrza, wody i hałasu poprzez zakupy aparatury kontrolno-pomiarowej i analitycznej dla sieci laboratoriów Inspekcji Ochrony 
nianych do 2030 r.) i przyrody ${ }^{19}$ oraz poprawy jakości powietrza ${ }^{20}$. Poprawa stanu jakości powietrza stanowi jeden z priorytetów rządu Rzeczypospolitej Polskiej.

Program Operacyjny Infrastruktura i Środowisko to największy program finansowany z Funduszy Europejskich nie tylko w Polsce, ale i Unii Europejskiej. Beneficjentami dofinansowania $\mathrm{w}$ ramach tego programu na lata $2014-2020$ są organy administracji rządowej, a także przedsiębiorcy. Program wspiera gospodarkę niskoemisyjną ${ }^{21}$, ochronę środowiska, przeciwdziałanie i adaptację do zmian klimatu, transport i bezpieczeństwo energetyczne. Środki unijne z programu przeznaczone są również w ograniczonym stopniu na inwestycje w obszary ochrony zdrowia i dziedzictwa kulturowego.

Ochrona środowiska naturalnego i bioróżnorodności to istotne zadania, w które angażują się instytucje publiczne. Liczne działania realizowane w zakresie ochrony środowiska nastawione są na unowocześnienie techniki gospodarowania zasobami i odpadami, zmniejszenie szkodliwości emisji gazów, wsparcie rozwoju przemysłu dla odnawialnych źródeł energii.

W przypadku Polski zakładanym celem, w którym spodziewane są największe efekty, jest poprawa efektywności energetycznej w obszarze budownictwa, zarówno publicznego, jak i mieszkaniowego, w sektorze ciepłownictwa oraz transportu. Dlatego promowane są projekty związane $\mathrm{z}$ modernizacją energetyczną budynków, w szczególności modernizacje sieci dystrybucji ciepła ${ }^{22}$. Duże przedsiębiorstwa motywowane są do wdrażania pozyskanych funduszy

\footnotetext{
Środowiska. Doskonalenie systemu zapewnienia jakości poprzez organizację laboratoriów wzorcujących i referencyjnych dla potrzeb wzmocnienia systemu zarządzania jakością środowiska i ocen efektów ekologicznych programu. Etap I projektu realizowano w latach 2008-2011, a jego całkowity koszt wyniósł 45426946,00 zł, z czego 38612904,00 zł zostało sfinansowane z Funduszu Spójności Programu Operacyjnego Infrastruktura i Środowisko, a 6814 042,00 zł z budżetu państwa.

${ }^{19}$ Przywrócenie ciągłości ekologicznej i realizacja działań poprawiających funkcjonowanie korytarza swobodnej migracji rzeki Białej Tarnowskiej. Program Operacyjny Infrastruktura i Środowisko. Całkowita wartość projektu: 39,3 mln zł, dofinansowanie z UE: 33,4 mln zł.

${ }^{20}$ Zob. O. Słobodzian-Ksenicz, M. Jasiewicz, D. Polus, Działania na rzecz redukcji emisji gazów cieplarnianych $w$ województwie lubuskim w latach 2010 - 2015, „Quaterly of Eenvironmental Engineering and Design" 2018, Vol. 169 (49), s. 12-27.

${ }^{21}$ „Budowa instalacji termicznego przekształcania frakcji energetycznej z odpadów pochodzących z odpadów komunalnych, z odzyskiem energii elektrycznej i cieplnej wraz z infrastrukturą towarzyszącą". Wnioskodawcą projektu jest Miejskie Przedsiębiorstwo Energetyki Cieplnej Sp. z o.o. w Olsztynie. Program Operacyjny Infrastruktura i Środowisko 2014-2020. Wartość projektu: 833402 287,63 zł, dofinansowanie z UE: 172405 017,30 zł.

22 Projekt hybrydowy „Kompleksowa termomodernizacja budynków na terenie miasta Zgierza”. Realizowany ze środków Unii Europejskiej z Europejskiego Funduszu Rozwoju Regionalnego w ramach Zintegrowanych Inwestycji Terytorialnych Regionalnego Programu Operacyjnego Województwa Łódzkiego na lata 2014-2020, Oś priorytetowa 4 Gospodarka niskoemisyjna. Wartość projektu: 52631 178,63 zł, dofinansowanie z UE: 35 226 754,02 zł.
} 
w zakresie zastosowania energooszczędnych (energia elektryczna, ciepło, chłód, woda) technologii produkcji, a także wprowadzanie nowoczesnych systemów zarządzania energią ${ }^{23}$. Warto również zwrócić uwagę na postulowane podniesienie standardów jakości powietrza, ponieważ problem zanieczyszczonego powietrza widoczny jest zwłaszcza w dużych miastach Polski zlokalizowanych na terenach aglomeracji śląsko-dąbrowskiej oraz krakowskiej ${ }^{24}$.

Rozbudowa Krajowego Systemu Elektroenergetycznego, zapewnienie niezależności energetycznej Polski są kluczowymi elementami bezpieczeństwa energetycznego. W Polsce największe oddziaływanie klimatu i ekstremalnych zdarzeń pogodowych występuje w sektorze gospodarki wodnej — częstsze zmiany temperatury, mniejsze miesięczne sumy opadów w okresie letnim, nawalne deszcze, podtopienia, fale upałów, susze, huragany. Jednym z założeń POIiŚ jest również adaptacja do zmian klimatu oraz efektywnego korzystania z zasobów, a także wzmocnienie odporności systemów gospodarczych na zagrożenia związane z klimatem i zwiększenie możliwości zapobiegania zagrożeniom, W szczególności zagrożeniom naturalnym ${ }^{25}$.

Warto również wspomnieć o projektach realizowanych dzięki wsparciu finansowemu z Programu LIFE, z którego dofinansowanie uzyskało blisko 4180 projektów z całej Europy, w tym 69 z Polski. LIFE składa się z dwóch podprogramów: Environment (dotacje na rzecz środowiska) oraz Climate Actions (dotacje na rzecz klimatu). Obecny LIFE — program działań na rzecz środowiska i klimatu, obejmujący perspektywę finansową 2014-2020, jest kontynuacją instrumentu finansowego LIFE+ funkcjonującego w latach 2007-2013. W ramach Programu LIFE Unia Europejska wspiera realizację projektów w dziedzinie środowiska, ochrony przyrody i klimatu ${ }^{26}$. Projekty realizowane w ramach LIFE

${ }^{23}$ Działanie 1.2 e Promowanie efektywności energetycznej i korzystania z odnawialnych źródeł energii w przedsiębiorstwach; Zob. E. Bień, EU Funds and Adaptation of Enterprises to the Requirements of Environmental Protection, „Desalination and Water Treatment” 2016, Vol. 57, Issue 3, s. 951-963.

${ }^{24}$ Poddziałanie 1.7.1 Wspieranie efektywności energetycznej w budynkach mieszkalnych w województwie śląskim i Działanie 2.5 Poprawa jakości środowiska miejskiego.

${ }^{25}$ Projekty: Ochrona przed powodzią Kotliny Kłodzkiej ze szczególnym uwzględnieniem ochrony Miasta Kłodzka; Zbiornik przeciwpowodziowy Racibórz Dolny na rzece Odrze w województwie śląskim. Projekt otrzymał unijne dofinansowanie na kwotę ponad $317 \mathrm{mln}$ zł z Programu Infrastruktura i Środowisko 2014-2020, Poddziałanie 2.1.4 Budowa, przebudowa lub remont urządzeń wodnych przyczyniających się do zmniejszenia skutków powodzi i suszy. Całkowity koszt inwestycji to niemal $545 \mathrm{mln}$ zł.

${ }^{26}$ Projekt „Polskie Ostoje Ptaków” nr LIFE09 NAT/PL/000263 ma na celu wdrażanie i doskonalenie aktywnej ochrony ptaków wodno-błotnych na obszarach o wysokim znaczeniu przyrodniczym. Prowadzony jest w pięciu polskich parkach narodowych: Biebrzańskim, Drawieńskim, Narwiańskim, Słowińskim oraz Parku Narodowym Ujścia Warty. Projekt jest finansowany ze środków Komisji Europejskiej (838951 euro) i Narodowego Funduszu Ochrony Środowiska i Gospodarki Wodnej (753 456 euro) w ramach instrumentu finansowego LIFE+ z całkowitym budżetem 1677902 euro; Wieloletni projekt „LIFE EKOMALOPOLSKA” (2021-2031) obej- 
to głównie duże i wieloletnie przedsięwzięcia mające na celu pełne wdrożenie strategicznych dokumentów dotyczących środowiska lub klimatu na szczeblu regionalnym lub krajowym. Beneficjentem programu może zostać każdy podmiot, tj. jednostki, podmioty i instytucje publiczne lub prywatne. W realizacji projektu może uczestniczyć kilka podmiotów, wśród których, poza beneficjentem głównym (koordynującym), mogą się znaleźć partnerzy oraz współfinansujący.

W Polsce realizowana jest III edycja Funduszy EOG i norweskich zaplanowana na lata 2014-2021. Fundusze norweskie związane są z przystąpieniem Polski do Unii Europejskiej oraz z jednoczesnym wejściem naszego kraju do Europejskiego Obszaru Gospodarczego (który tworzą państwa UE oraz Islandia, Liechtenstein i Norwegia). W zamian za udzielaną pomoc finansową, państwa-darczyńcy korzystają z dostępu do rynku wewnętrznego UE, mimo że nie są jej członkami. Głównym celem Funduszy norweskich i Funduszy EOG jest zmniejszanie różnic ekonomicznych i społecznych w obrębie EOG oraz wzmacnianie stosunków dwustronnych pomiędzy państwami-darczyńcami a państwem-beneficjentem ${ }^{27}$.

W ramach obszaru priorytetowego Środowisko realizowany jest Program „Środowisko, Energia i Zmiany Klimatu”, którego operatorem jest Ministerstwo Klimatu przy wsparciu Narodowego Funduszu Ochrony Środowiska i Gospodarki Wodnej. Program „Środowisko, Energia i Zmiany Klimatu” ma zapewnić poprawę jakości powietrza i efektywne wykorzystanie energii w szkołach i przedsiębiorstwach, a także zwiększenie produkcji energii ze źródeł odnawialnych oraz przeciwdziałanie zmianom klimatu ${ }^{28}$. Środki finansowe mają zostać przeznaczone na poprawę efektywności energetycznej i bezpieczeństwa energetycznego i obejmują takie przedsięwzięcia, jak: termomodernizacja budynków użyteczności publicznej — szkół podstawowych i ponadpodstawowych, budo-

muje m.in.: implementację Regionalnego Planu Działań dla Klimatu i Energii, niskoemisyjną transformację rynku urządzeń grzewczych, tworzenie narzędzi informatycznych określających potencjał OZE, przygotowanie regionalnego centrum kompetencji wspierającego powiaty i gminy, a także pilotaże w zakresie klastrów energetycznych, spółdzielni energetycznych, biogazowni rolniczych oraz wykorzystania biomasy odpadowej. Wartość inwestycji to ponad $70 \mathrm{mln}$ zł (w tym dofinansowanie z KE: ponad 9,8 mln euro z KE, ponad 24,6 mln zł z NFOŚiGW oraz ponad 3,5 mln zł wkładu własnego); „Wdrażanie planu gospodarowania wodami w dorzeczu Wisły na przykładzie zlewni Pilicy” (2021-2030) służy poprawie jakości i różnorodności biologicznej wód w zlewni Pilicy, ze szczególnym uwzględnieniem zbiornika Sulejów. Koszt tego przedsięwzięcia to prawie $74 \mathrm{mln}$ zł (dofinansowanie z KE: prawie 9,8 mln euro, NFOŚiGW: ponad $25 \mathrm{mln}$ zł oraz budżet państwa: ponad 5,8 mln zł).

27 A. Klementowska, Przedsięwzięcia proekologiczne w poradnictwie zawodowym na przykładzie programów oferowanych przez NFOŚIGW, „Forum Pedagogiczne” 2016, T. 6, nr 2/2, s. 104.

${ }^{28}$ Budżet całkowity Programu „Środowisko, Energia i Zmiany Klimatu” to $164,7 \mathrm{mln}$ euro, z których $140 \mathrm{mln}$ euro stanowią środki Mechanizmu Finansowego EOG, a 24,7 mln euro to wkład $\mathrm{z}$ budżetu państwa. 
wa/modernizacja miejskich systemów ciepłowniczych, kogeneracji oraz likwidacja indywidualnych źródeł ciepła, a także budowa instalacji do wytwarzania paliwa (pelletów) z biomasy leśnej i agro. $\mathrm{W}$ ramach obszaru środowisko naturalne i ekosystemy przyznane fundusze zostaną przeznaczone na prowadzenie czynnej ochrony zagrożonych gatunków i siedlisk, zwalczanie inwazyjnych gatunków obcych oraz przeciwdziałanie ich rozprzestrzenianiu. Beneficjentami funduszy norweskich mogą zostać przede wszystkim jednostki samorządu terytorialnego, szkoły, uczelnie, organizacje pozarządowe, instytucje kultury oraz zakłady opieki zdrowotnej.

\section{Umowa o dofinansowanie projektu}

Kluczowe znaczenie dla realizacji projektu współfinansowanego z funduszy strukturalnych ma umowa o dofinansowanie projektu, jej zawarcie kończy etap procesu wyboru projektu do dofinansowania ${ }^{29}$. Umowa o dofinansowanie projektu zawarta $\mathrm{z}$ beneficjentem przez instytucję zarządzającą albo działającą w jej imieniu instytucję pośredniczącą lub instytucję wdrażającą stanowi podstawę dofinansowania projektu ${ }^{30}$. Umowa o dofinansowanie projektu jest umową dotacji w rozumieniu art. 206 ust. 2 ustawy z dnia 27 sierpnia 2009 r. o finansach publicznych ${ }^{31}$.

W doktrynie funkcjonują rozbieżne stanowiska na temat charakteru prawnego tej umowy ${ }^{32}$. Zdaniem R. Szostaka to brak ustawowych wskazówek powoduje tak liczne wątpliwości dotyczące charakteru prawnego tej umowy, zdecydowanie jednak przeważa opinia o jej cywilnoprawnej naturze ${ }^{33}$. Umowa o dofinansowanie projektu posiada również cechy umowy adhezyjnej. Zwolennicy tej tezy podnoszą jako jeden z podstawowych argumentów obowiązujące

29 Projekt - przedsięwzięcie realizowane w ramach programu operacyjnego na podstawie decyzji lub umowy o dofinansowanie zawieranej między beneficjentem a instytucją zarządzającą, instytucją pośredniczącą lub instytucją wdrażającą, zgodnie z definicją określoną w art. 5 pkt 9 ustawy z dnia 6 grudnia 2006 r. o zasadach prowadzenia polityki rozwoju (t.j. Dz.U. 2019, poz. 1295 ze zm.).

30 Zgodnie z art. 30 ust.1 ustawy o zasadach prowadzenia polityki rozwoju podstawa dofinansowania może również wynikać z indywidualnej decyzji administracyjnej właściwego organu, jeśli instytucja zarządzająca (pośrednicząca) jest jednocześnie beneficjentem pomocy ze środków europejskich.

31 T.j. Dz.U. 2019, poz. 869 ze zm., dalej: u.o.f.p.

32 R. Talaga, Ewolucja umowy o dofinansowanie projektu ze środków europejskich w polskim systemie prawnym, „Ius Novum” 2019, Vol. 13, nr 1, s. 177-191.

33 R. Szostak, Kontrola zamówień publicznych finansowanych ze środków europejskich zagadnienia organizacyjne, „Samorząd Terytorialny” 2011, nr 11, s. 61-79. 
wzorce umów. Odmienne stanowisko prezentuje R. Iniewski, który podnosi, iż nie można takiego charakteru wywodzić z art. 206 ust. 2 u.o.f.p., a w związku z tym możliwe jest negocjowanie warunków i postanowień przyszłej umowy o dofinansowanie ${ }^{34}$. Oczywiście nie można odmówić racji tym twierdzeniom, jednak na takie wzorce należy patrzeć jak na postanowienia regulujące essentialia negotii przyszłej umowy o dofinansowanie. Treść wzoru umowy o dofinansowanie projektu stanowi zatem minimalny zakres, który może być przez strony umowy uzupełniany o inne postanowienia niezbędne dla realizacji projektu - mogą tego dokonać również strony negocjowana, co jednak w praktyce rzadko ma miejsce ${ }^{35}$.

Umowa o dofinansowanie projektu nie jest jednak typową umową cywilnoprawną. Fakt ten podkreślił Naczelny Sąd Administracyjny w uchwale z 27 października 2014 r. W orzeczeniu wskazano: „Po analizie regulacji ustawowych i umownych dotyczących powstałego stosunku dofinansowania trzeba stwierdzić, że nie wszystkie elementy tej relacji mają charakter cywilnoprawny. Ustawodawca wprowadził do tych stosunków prawnych, łączących strony umowy o dofinansowanie, elementy publicznoprawne, stanowiące dodatkowe gwarancje, zapewniające prawidłową realizację umowy. Wyposażył instytucję zarządzającą w atrybut władzy administracyjnej w postaci orzekania o zwrocie dofinansowania w drodze decyzji administracyjnej" ${ }^{36}$. W konsekwencji realizacja umowy o dofinansowanie poddawana jest kontroli zarówno sądów cywilnych, jak i administracyjnych.

\section{Podsumowanie}

Postępująca degradacja środowiska naturalnego ma charakter globalny, ponieważ człowiek na całym świecie wykorzystuje bogactwa natury. W Polsce środowisko zanieczyszczane jest głównie przez przemysł, który wytwarza olbrzymie ilości pyłów, gazów, ścieków i odpadów stałych. Ponadto transport drogowy emituje do atmosfery spaliny samochodowe, a z gospodarstw domowych pochodzą śmieci i ścieki komunalne, z niektórych także spaliny z domowych pieców oraz kotłów centralnego ogrzewania. Dlatego tak istotne jest realizowanie działań, których cel stanowi utrzymanie procesów ekologicznych i stabilności ekosystemów, zachowanie różnorodności biologicznej, a także zachowanie

34 Zob. R. Iniewski, Nowa umowa o dofinansowanie projektu, „Finanse Publiczne” 2010, nr 3, s. 58 i nast.

35 A. Piwowarczyk, Rola zamówień publicznych $w$ realizacji polityki spójności w perspektywie 2014-2020, „PZP Prawo Zamówień Publicznych” 2020, nr 1 (64), s. 81—94.

${ }^{36}$ Uchwała NSA z dnia 27 października 2014 r., sygn. akt II GPS 2/14. 
dziedzictwa geologicznego i paleontologicznego. Ważne jest również utrzymanie lub przywracanie do właściwego stanu siedlisk przyrodniczych, a także zasobów, tworów i składników przyrody. Wszystkie przedsięwzięcia, których celem jest szeroko rozumiana ochrona środowiska, realizowane mogą być dzięki wsparciu z funduszy unijnych.

Środki unijne wdrażane poprzez realizowane programy operacyjne zapewniły Polsce dynamiczny rozwój gospodarczy i społeczny, a także umożliwiły realizację wielu projektów prośrodowiskowych. Kończąca się bieżąca perspektywa finansowa 2014-2020 nie oznacza jednak, że wsparcie finansowe ze środków UE zostanie wstrzymane. Strategia na rzecz Odpowiedzialnego Rozwoju zakłada bowiem, że istotnym źródłem finansowania polityki gospodarczej w Polsce będzie Unia Europejska, w tym przede wszystkim środki w ramach europejskiej polityki spójności ${ }^{37}$.

W nowej perspektywie finansowej 2021-2027 planowana jest kontynuacja działań związanych z adaptacją do zmian klimatu na terenach zurbanizowanych. Prawdopodobnie podstawą dla ubiegania się o dofinansowanie ze środków unijnych dla inwestycji w tym zakresie będą miejskie plany adaptacji. Już teraz można uzyskać wsparcie finansowe z Narodowego Funduszu Ochrony Środowiska i Gospodarki Wodnej, który prowadzi nabór wniosków w programie priorytetowym 5.4 „Adaptacja do zmian klimatu oraz ograniczenie zagrożeń środowiska". Parlament i Rada UE zawarły wstępne porozumienie w sprawie programu działań na rzecz środowiska i klimatu LIFE w latach 2021—2027. W nowej perspektywie finansowej LIFE ma być programem, który otrzyma proporcjonalnie najwyższy budżet. Komisja Europejska proponuje również, aby co najmniej $25 \%$ wydatków UE we wszystkich programach przyczyniało się do realizacji celów klimatycznych.

Celem finansowania UE będzie ochrona środowiska i łagodzenie skutków zmiany klimatu, wspieranie przejścia na czystą energię, poprawa efektywności energetycznej i wzrost udziału odnawialnych źródeł energii. Będzie to jedno z narzędzi, dzięki którym UE będzie mogła zrealizować swoje cele w dziedzinie klimatu i dążyć do osiągnięcia neutralności klimatycznej do $2050 \mathrm{r}$.

\section{Literatura}

Bień E., EU Funds and Adaptation of Enterprises to the Requirements of Environmental Protection, „Desalination and Water Treatment” 2016, Vol. 57, Issue 3, s. 951-963.

Bień E., Management of Available EU Funds and The State of Municipal Waste Management in Poland, in: Proceedings of the 35th International Business Information Management Asso-

${ }^{37}$ Uchwała nr 8 Rady Ministrów z dnia 14 lutego 2017 r. w sprawie przyjęcia Strategii na rzecz Odpowiedzialnego Rozwoju do roku 2020 (z perspektywą do 2030 r.), M.P. 2017, poz. 260. 
ciation Conference, Education Excellence and Innovation Management: A 2025 Vision to Sustain Economic Development during Global Challenges, ed. Khalid S. Soliman, Sewilla 2020, s. 9593-9606.

Bylicki L., Ochrona środowiska w Unii Europejskiej, „Zeszyty Naukowe PWSZ w Płocku Nauki Ekonomiczne" 2014, T. 290, s. 185-199.

Gasz M., Strategia Europa 2020 - założenia i perspektywy realizacji, „Nierówności Społeczne a Wzrost Gospodarczy" 2014, Issue 38, s. 85-97.

Iniewski R., Nowa umowa o dofinansowanie projektu, „Finanse Publiczne” 2010, nr 3, s. 58-60.

Klementowska A., Przedsięwzięcia proekologiczne w poradnictwie zawodowym na przyktadzie programów oferowanych przez NFOŚIGW, „Forum Pedagogiczne” 2016, T. 6, nr 2/2, s. $95-105$.

Kożuch M., Zmiany w finansowaniu przedsięwzięć ochrony środowiska przyrodniczego w Polsce, „Zeszyty Naukowe Uniwersytet Ekonomiczny w Krakowie” 2018, nr 1 (973), s. 61-78.

McCormick J., Zrozumieć Unię Europejska, Wydawnictwo Naukowe PWN, Warszawa 2010.

Michalik E., Wspieranie rozwoju regionalnego w Polsce w perspektywie finansowej 2014-2020, „Studia Ekonomiczne” 2017, nr 319, s. 127-136.

Piwowarczyk A., Rola zamówień publicznych w realizacji polityki spójności w perspektywie 2014-2020, „PZP Prawo Zamówień Publicznych” 2020, nr 1 (64), s. 81—94.

Ryszkiewicz A., Od konwergencji do spójności i efektywności, Szkoła Główna Handlowa. Oficyna Wydawnicza, Warszawa 2013.

Słobodzian-Ksenicz O., Jasiewicz M., Polus D., Działania na rzecz redukcji emisji gazów cieplarnianych $w$ województwie lubuskim w latach 2010 - 2015, „Quaterly of Eenvironmental Engineering and Design" 2018, Vol. 169 (49), s. 12-27.

Szlachta J., Polityka rozwojowa w kontekście polityki spójności - przypadek Polski w latach 2014-2020, „Prace i Materiały Instytutu Rozwoju Gospodarczego SGH” 2016, Vol. 98, s. $131-150$.

Szostak R., Kontrola zamówień publicznych finansowanych ze środków europejskich - zagadnienia organizacyjne, „Samorząd Terytorialny” 2011, nr 11, s. 61-79.

Talaga R., Ewolucja umowy o dofinansowanie projektu ze środków europejskich w polskim systemie prawnym, „Ius Novum” 2019, Vol. 13, nr 1, s. 177-191.

Ulfik A., Regional Use of European Funds in Municipal Waste Management in Poland, „European Journal of Service Management” 2018, Vol. 27/1, 3/2018, s. 351-356.

\section{Agnieszka Piwowarczyk}

\section{Pro-environmental projects financed from EU funds}

\section{Summary}

The EU promotes the implementation of pro-ecological solutions in the member states to restore the environment in order to improve the living conditions of the citizens. Co-financing for the implementation of projects supporting the protection of climate change is mainly provided under the Infrastructure and Environment Operational Program, as well as Regional Operational Programs and the Cohesion Fund. The aim of the article is to show how helpful measures will contribute to the improvement of the favorable environment.

The dogmatic and legal analysis was used as the basic research method, which made it possible to select the extent to which EU funds support pro-environmental activities.

Keywords: environmental protection, EU funds, pro-environmental activities. 


\section{Агнешка Пивоварчик}

\section{Природоохранная деятельность, финансируемая из фондов ЕС}

\section{Резюме}

Европейский Союз популяризирует внедрение природоохранных мер с целью улучшению условий жизни граждан государств-членов за счет улучшения состояния окружающей среды. Софинансирование реализации проектов, поддерживающих защиту климата, осуществляется в основном в рамках Операционной программы по инфраструктуре и окружающей среде, а также региональных операционных программ и Фонда сплочения. Цель статьи - показать, как использование средств ЕС влияет на охрану окружающей среды.

В исследовании использовался догматическо-правовой анализ в качестве основного метода исследования, который позволил оценить, в какой степени фонды ЕС поддерживают природоохранную деятельность.

Кл ючевые слова: охрана окружающей среды, фонды ЕС, природоохранная деятельность.

\section{Agnieszka Piwowarczyk}

\section{Progetti ambientali finanziati da fondi UE}

\section{Sommario}

L'Unione europea promuove l'attuazione di iniziative ambientali volte a migliorare le condizioni di vita dei cittadini degli Stati membri migliorando l'ambiente. Le sovvenzioni per l'attuazione di progetti a sostegno della protezione del clima sono attuate principalmente nell'ambito del programma operativo per le infrastrutture e l'ambiente, nonché dei programmi operativi regionali e del Fondo di coesione. Lo scopo dell'articolo è quello di mostrare come l'utilizzo dei fondi UE influisce sulla protezione dell'ambiente.

Nella ricerca è stata utilizzata un'analisi dogmatica e giuridica come metodo di ricerca di base, che ha permesso di valutare in che misura i fondi UE sostengono le attività a favore dell'ambiente.

Parole chiave: protezione dell'ambiente, misure UE, azioni ambientali 